\title{
Identification, Antagonistic Potentials and Plasmid Profiling of Micro-Organisms Associated with Termitarium from Cocoa Trees in Ibule-Soro, Akure Nigeria
}

\section{JO Aribisala*, MK Oladunmoye, OI Afolami and T Aina}

Department of Microbiology, Federal University of Technology, Akure, Nigeria

*Corresponding Author: JO Aribisala, Department of Microbiology, Federal University of Technology, Akure, Nigeria.

Received: January 02, 2017; Published: February 03, 2018

DOI: $10.31080 /$ ASMI.2018.01.0020

\begin{abstract}
This research identified micro-organisms associated with termitarium on cocoa trees and cocoa tree bark cultivated in Ibule-soro, Akure, Ondo State Nigeria. Bacteria such as Kocuria spp, Micrococcus spp, Bacillus cereus and Clostridium botulinum were identified, while fungi isolates such as Histoplasma capsulatum, Penicillium notatum, Microsporum audouinii, Aspergillus flavus, Cladosporium cladosporioides were also identified from the termitarium sampled from the farm settlements in Ibule-soro in Ondo State Nigeria. The antagonistic properties of the isolated bacteria and fungi were evaluated to determine the growth inhibitory effects of the isolated organisms against some selected pathogens. The selected pathogens were Escherichia coli and Shigella spp for the gram negative and Staphylococcus aureus for the gram positive. Antimicrobial sensitivity patterns of isolated bacteria from termitarium and cocoa tree bark were also evaluated using Kirby-Bauer test. The multiple drug resistant isolates (MDRIs) which include Kocuria spp and Micrococcus spp were screened out of the bacteria isolates obtained. Plasmid profile analysis of screened multiple drug resistant isolates revealed possession of plasmids with Kocuria spp and Micrococcus spp having a plasmid weight of $1000 \mathrm{bp}$ and $980 \mathrm{bp}$ respectively. Plasmid curing of the selected multiple drug resistance isolates was carried out and the cured bacterial isolates were subjected again to broad spectrum antibiotic test to determine the basis of the antibiotic resistance. The initially observed antibiotic resistance for MDRIs was extra chromosomal since screened isolates were susceptible to broad spectrum antibiotics after curing. The Antagonistic test shows that only Penicillium notatum had mild antagonistic effect on the selected test pathogens while the remaining fungi and bacterial isolate had no significant antagonistic properties.
\end{abstract}

Keywords: Antagonistic; Plasmid Profiling; Termitarium; Resistance; Cocoa Trees

\section{Introduction}

Termites are commonly called white ants. They are soft-bodied, social and polymorphic insects having two pairs of similar deciduous wings and live together forming large communities. The termites, however, are among the most destructive insects so far as man is concerned but in nature they help in decomposing the dead vegetation and enriching the soil [1]. Though the termites are called white ants but they are neither completely white in colour nor ants; one can easily differentiate these from ants by the absence of a constriction or peduncle between the thorax and the abdomen, in addition to some other morphological and behavioral characteristics. The termites are nocturnal and they prefer to live in eternal darkness. They cannot withstand the exposure of dry air and, therefore, they construct tunnels in the earth and wood. The termites are best known nest building insects [2]. Termites are the cause of huge damage to man. Since, their main food is cellulose, hence, they injure and destroy the wood work of houses, timbers, furniture's, railway sleepers, wooden bridges, boats, telegraph poles, books, large orchard trees like mango, apple, coconut, cashew, citrus, guava, and many field crops like sugarcane, groundnut, tea, coffee, cotton, potato plants, etc., are badly damaged by them [3]. Since, they bore through wood causing much damage; they can digest wood with the help of symbiotic flagellates, such as Trichonympha campanula living in their intestine and passed on from generation to generation. These are social insects forming large communities and well-marked polymorphic individuals. However, more than 1700 species of termites are known today. Some common genera are Macrotermes, Mastotermes, Odontotermes, Kalotermes, Nasutitermes, Leucotermes, Coptotermes, Achotermopsis, Zootermopsis etc $[4]$.

Theobroma cacao is one of the world's most valuable crops, cultivated worldwide on 8.2 million hectares, grown in 58 countries, and worth over US\$4 billion annually. Cocoa is a well-adapted agroforestry plantation crop grown in hot, rainy climates with cultivation concentrated in a band between 0 to 20 degrees north and south of the Equator, sometimes called the "Cocoa Belt" [5]. Economic cocoa cultivars are grown for the production of dried beans, which are the source of cocoa liquor, cocoa butter, cocoa cake and cocoa powder. Cocoa is a fast- growing tropical forest plant, capable of being cultivated in association with other trees, and providing additional goods like timber and firewood, fruits, construction materials, honey, resin, medicine and materials for ritual ceremonies [6]. Termitarium is the nest of termites comprised of partially digested food materials and fecal matter of termites, enriched with minerals and other organic constituents, which provides a suitable environment for the existence of a huge diversity of microorganisms [2]. The microbial population of dual origins from both termites and neighboring soil might result in greater microbial diver- 
sity in the termitarium than termite gut or termite-associated soil. However, only a few reports are available on the microbial diversity of termitarium [7]. In this study, there is need for exploration of this nest in other to know the possibility of discovering novel microorganisms.

\section{Materials and Methods}

Sample Collection

Samples of termite termitarium and cocoa tree bark was collected into sterile cup with air tight lids from farm settlement in Ibule-soro, Ondo State Nigeria. All samples collected were analysed within 6 hours of sample collection.

\section{Sample Preparation}

The method described by Fall., et al. [7] was adopted for sample preparation. Using a sterile syringe, a $9 \mathrm{ml}$ of sterile distilled water was dispensed into 3 different test tubes under aseptic conditions and a $1 \mathrm{~g}$ of the termitarium was poured into the first test tube, homogenized and a $1 \mathrm{ml}$ was taken out for a serial dilution procedure till the 5th dilution was obtained. A $1 \mathrm{ml}$ of the last dilution factor was seeded on already sterilize media for fungal and bacterial isolation [8]

Isolation and Sub-culturing of Bacteria and Fungi from Termitarium and Cocoa Tree Bark

Pour plate method was employed for the isolation as described by Fawole and Oso [8] in which $1 \mathrm{ml}$ of the prepared samples were seeded on nutrient and potato dextrose agar aseptically for bacteria and fungi isolation respectively and were incubated at $37^{\circ} \mathrm{C}$ for 24 hours for bacteria and $25^{\circ} \mathrm{C}$ for 3 days for fungi. Sub culturing of the obtained colonies of bacteria and fungi were carried out on freshly prepared nutrient and Potato Dextrose Agar respectively.

Identification and Characterization of Isolated Bacteria an Fung

Standard and conventional methods of cultural, morphological and biochemical characteristics were employed in the identification of the organisms following the method of Sarah., et al [9].

\section{Antibiotic Sensitivity Screening of Bacterial Isolates}

The antibiotic susceptibility testing was carried out using KirbyBauer method as described by Cheesebrough (2006) [10]. A loop full of a bacteria colony was picked and emulsified in a Bijou bottle containing $3.0 \mathrm{ml}$ of normal saline. A cotton swab was dipped into the suspension and the swab was pressed against the side of the bottle to remove excess fluid. The inoculated swab was then streaked across the surface of Mueller Hinton agar and allowed to dry for five minutes after which sterile forceps were used to carefully remove the disc from its pack and gently pressed onto the agar surface. The plates were incubated at $370 \mathrm{C}$ for 24 hours. The zones of inhibition were measured in millimeters using a ruler
Antibiotic sensitivity screening was also carried out on multiple drug resistant isolates already cured of their plasmids with broad spectrum antibiotics (CM128PR100).

Antagonistic Test

\section{Bacteria against Bacteria}

This test was carried out on Mueller Hinton agar on petri dishes using dual culture method [11]. 18 hours cultures of the preserved isolates were plated using Mueller Hinton agar. Selected bacteria pathogens, namely; Escherichia coli, Shigella spp and Staphylococcus aureus were sourced as clinical samples from the medical laboratory section of the Ondo State General Hospital, Akure, Nigeria and used against the obtained isolates. The test was carried out by streaking the test organism on one side of the agar plate and the known pathogen on the other side of the agar plate as described in findings of Fokkema and Van den [11].

\section{Fungi against Bacteria}

This test was carried out on Mueller Hinton agar. Fungi isolates from a slant were sub cultured on potato dextrose agar for 72 hours [11]. Selected bacteria pathogen as used in the bacteria antagonistic test was also used. A $5 \mathrm{~mm}$ cork borer was used to cut out the diameter from the fungal growth into the centre of the fresh Mueller Hinton agar, and the known bacteria pathogen was streaked on the side of the fungi about $5 \mathrm{~mm}$ apart. The paired cultured plates were incubated at $25^{\circ} \mathrm{C}$ for 7 days and the zone of inhibition was observed [11].

Plasmid Profile Analysis

An 18 hours old broth culture was used for this analysis. The procedure described by CLSI [12] was adopted for this analysis.

\section{Plasmid Curing}

The plasmid curing was done by exposing the overnight grown culture at $37^{\circ} \mathrm{C}$ and $10 \mathrm{mg} / \mathrm{ml}$ of Ethidium bromide. After plasmid curing, isolates were subjected to antibiotic sensitivity test again using broad spectrum antibiotics (CM128PR100) [13]

Result

Bacteria Isolates from Termitarium and Cocoa Bark

Bacillus spp and Clostridium spp were isolated from the termitarium in this research. Gram staining showed the organisms to be gram positive. With subsequent biochemical tests results obtained, they were found to be motile, catalase positive, coagulase negative and were consistent in carbon source utilization. Organisms isolated from cocoa tree back with regards to their morphology and biochemical characteristics include; Micrococcus spp and Kocuria spp.

\begin{tabular}{|c|c|c|c|c|c|c|c|c|c|c|c|c|c|}
\hline \multirow[t]{2}{*}{ I } & \multirow[t]{2}{*}{ Gram } & \multicolumn{5}{|c|}{ Sugar Fermentation } & \multirow[t]{2}{*}{ COT } & \multirow[t]{2}{*}{ CAT } & \multirow[t]{2}{*}{ OX } & \multirow[t]{2}{*}{ SP } & \multirow[t]{2}{*}{ MOT } & \multirow[t]{2}{*}{ VP/MR } & \multirow[t]{2}{*}{ N.I } \\
\hline & & Suc. & Lac. & Glu. & Mann. & T.S.I & & & & & & & \\
\hline K.S. & +ve non-cluster cocci & -ve & -ve & $+\mathrm{ve}$ & -ve & N.A & -ve & $+\mathrm{ve}$ & $+\mathrm{ve}$ & -ve & -ve & -ve/-ve & 2 \\
\hline M.S & +ve cluster cocci & $+v e$ & -ve & +ve & -ve & N.A & -ve & $+\mathrm{ve}$ & $+\mathrm{ve}$ & -ve & -ve & -ve/-ve & 3 \\
\hline B.C & +ve bacilli rods & $+v e$ & -ve & $+\mathrm{ve}$ & -ve & A.K.P & -ve & $+\mathrm{ve}$ & $+\mathrm{ve}$ & +ve (terminal) & $+\mathrm{ve}$ & $+\mathrm{ve} /+\mathrm{ve}$ & 2 \\
\hline C.S & +ve spiral rods & $+v e$ & -ve & $+\mathrm{ve}$ & -ve & N.A & -ve & $+\mathrm{ve}$ & $+\mathrm{ve}$ & +ve (central) & $+v e$ & -ve/-ve & 4 \\
\hline
\end{tabular}

Table 1: Morphological and Biochemical Characteristics of Bacterial Isolates.

Keys: I: Isolate; K.S.: Kocuria spp; M.S: Micrococcus spp; B.C: Bacillus spp; C.S: Clostridium spp; Suc: Sucrose; Lac: Lactose; Glu: Glucose; Mann: Mannitol; T.S.I: Triple Salt Iron; COT: Coagulase Test; CAT: Catalase Test; OX: Oxidase Test; S: Spore Test MOT: Motility Test; VP/MR: Vogues Proskauer/Methyl red; +ve: Postive; -ve: Negative; NA: Not Applicable; A.K.P: Alkaline Slant Produced

Fungal Isolates from Cocoa Termitarium and Tree Bark

Five different fungi were isolated from the termitarium and the tree bark. Their microscopic and macroscopic characteristics vary uniquely as shown in table 2 .

\section{Antimicrobial Sensitivity Result}

Test results shows that Bacillus spp and Clostridium spp were more sensitive to most of the antibiotics than Micrococcus spp which was resistance to about six of the antibiotics. Kocuria spp was totally resistant to the antibiotics thus necessitating for a plasmid profile analysis using electrophoresis. The antimicrobia characteristics are clearly represented on table 3 and table 4. 
Identification, Antagonistic Potentials and Plasmid Profiling of Micro-Organisms Associated with Termitarium from Cocoa Trees in Ibule-Soro, Akure Nigeria

\begin{tabular}{|c|c|c|c|}
\hline $\begin{array}{c}\text { Fungal } \\
\text { isolates }\end{array}$ & Macroscopic & Microscopic & Probable organism \\
\hline Isolate 1 & $\begin{array}{c}\text { Colonies are black with a pale yellow } \\
\text { reverse side }\end{array}$ & $\begin{array}{l}\text { Hypha is septate. Simple upright conidio- } \\
\text { phores that terminates in glucose Swelling, } \\
\text { bearing phialides at the apex or radiating form } \\
\text { the entire surface. Conidia are one-celled and } \\
\text { globose. }\end{array}$ & Penicillium notatum \\
\hline Isolate 2 & $\begin{array}{c}\text { Colonies are flat, spreading, greyish- } \\
\text { white to light tan white in colour. Re- } \\
\text { verse is yellow-brown to reddish-brown } \\
\text { in colour. }\end{array}$ & $\begin{array}{l}\text { A thick-walled intercalary } \\
\text { Chlamydospore }\end{array}$ & Microsporium audouinii \\
\hline Isolate 3 & $\begin{array}{c}\text { Colonies are granular, flat, often with } \\
\text { radial grooves, yellow at first but quickly } \\
\text { becoming bright to dark yellow-green } \\
\text { with age. }\end{array}$ & $\begin{array}{l}\text { Conidial heads are typically radiate, later split- } \\
\text { ting to form loose columns (mostly } \\
\qquad 300-400 \mu \mathrm{m} \text { in diameter). }\end{array}$ & Aspergillus flavus. \\
\hline Isolate 4 & $\begin{array}{c}\text { Colonies at } 25^{\circ} \mathrm{C} \text { are slow growing, white } \\
\text { or buff-brown, suede-like to cottony with } \\
\text { a pale yellow-brown reverse. Exhibiting } \\
\text { a budding yeast-like fungus. }\end{array}$ & $\begin{array}{l}\text { Numerous small round to oval budding yeast- } \\
\text { like cells, } 3-4 \times 2-3 \mu \mathrm{m} \text { in size are observed. }\end{array}$ & Histoplasma capsulatum \\
\hline Isolate 5 & $\begin{array}{c}\text { Colonies are slow growing, mostly } \\
\text { olivaceous-brown to blackish-brown but } \\
\text { also sometimes grey. }\end{array}$ & $\begin{array}{l}\text { Vegetative hyphae, being erect, straight or } \\
\text { flexuose, unbranched or branched only in the } \\
\text { apical region }\end{array}$ & $\begin{array}{l}\text { Cladosporium cladospo- } \\
\text { rioides. }\end{array}$ \\
\hline
\end{tabular}

Table 2: Macroscopic and Microscopic characteristics of fungal isolates.

\begin{tabular}{|c|c|c|c|c|c|c|c|c|c|c|c|}
\hline \multirow[b]{2}{*}{ I.C } & \multicolumn{10}{|c|}{ Antibiotic used with zones of inhibition (mm) } & \multirow[b]{2}{*}{ N.I } \\
\hline & ERY 5 ųg & CPX 10 ugg & $\begin{array}{c}\text { COT } 25 \\
\text { ug }\end{array}$ & $\begin{array}{l}\text { AMX } 25 \\
\text { ugg }\end{array}$ & OFL 5 ųg & $\begin{array}{c}\text { STR } 10 \\
\text { ugg }\end{array}$ & $\begin{array}{c}\text { CHL } 30 \\
\text { ug }\end{array}$ & $\begin{array}{c}\text { CEF } 30 \\
\text { uqg }\end{array}$ & $\begin{array}{c}\text { GEN } 10 \\
\text { ugg }\end{array}$ & PEF 5 ųg & \\
\hline K. spp & 00.00 & 00.00 & 00.00 & 00.00 & 00.00 & 00.00 & 00.00 & 00.00 & 00.00 & 00.00 & 2 \\
\hline B.C & $16 \pm 0.8$ & $22 \pm 1.2$ & 00.00 & 00.00 & $17 \pm 2.2$ & $11 \pm 0.7$ & $13 \pm 0.7$ & 00.00 & $17 \pm 1.4$ & 23.00 & 2 \\
\hline C.B & 00.00 & $21 \pm 1.4$ & $21 \pm 1.6$ & 00.00 & $24 \pm 0.8$ & 00.00 & $20 \pm 0.8$ & 00.00 & $21 \pm 0.9$ & $24 \pm 1.8$ & 4 \\
\hline M. spp & 00.00 & 00.00 & 00.00 & 00.00 & 00.00 & $11 \pm 1.2$ & $16 \pm 0.8$ & $13 \pm 1.6$ & $11 \pm 1.4$ & 00.00 & 3 \\
\hline
\end{tabular}

Table 3: Zones of inhibition of bacteria isolates against antibiotics.

Keys: OFL: Ofloxacin; STR: Streptomycin; CHL: chloramphenicol; GEN: Gentamycin; PEF: Pefloxacin; CEF: Ceftriaxone; COT: Cotrimoxazole; CPX: Ciprofloxacin; ERY: Erythromycin; AMX: Amoxycillin; N.I: Number of Isolates; 0-10 mm: Resistant; 11-16: Intermediate; 16-above-susceptible (Cheesebrough; 2006); C.I.: Codes of Isolates; K.S.: Kocuria spp; M.S: Micrococcus spp; B.C: Bacillus spp; C.S: Clostridium botulinum

\begin{tabular}{|l|c|c|c|c|c|c|c|c|c|c|c|}
\hline \multirow{3}{*}{ I.C } & \multicolumn{8}{|c|}{ Antibiotic used with zones of inhibition (mm) } & \multirow{2}{*}{ N.I } \\
\cline { 2 - 13 } & ERY & CPX & COT & AMX & OFL & STR & CHL & CEF & GEN & PEF & \\
\hline K. Spp & R & R & R & R & R & R & R & R & R & R & 2 \\
\hline M. spp & R & R & R & R & R & I & S & I & I & R & 3 \\
\hline B.C & S & S & R & R & S & I & I & R & S & S & 2 \\
\hline C.B & R & S & S & R & S & R & S & R & S & S & 4 \\
\hline
\end{tabular}

Table 4: Antibiotic sensitivity patterns of bacteria isolates.

Keys: OFL: Ofloxacin; STR: Streptomycin; CHL: chloramphenicol; GEN: Gentamycin; PEF: Pefloxacin; CEF: Ceftriaxone; COT: Cotrimoxazole; CPX: Ciprofloxacin; ERY: Erythromycin; AMX: Amoxycillin. N.I: number of isolates; 0-10 mm: Resistant; 11-16: Intermediate; 16-above-susceptible (Cheesebrough; 2006); I: intermediate; R-resistant and S: susceptible; C.I: codes of isolates; K.S.: Kocuria spp; M.S: Micrococcus spp; B.C: Bacillus spp; C.S: Clostridium botulinum.

Citation: JO Aribisala., et al. "Identification, Antagonistic Potentials and Plasmid Profiling of Micro-Organisms Associated with Termitarium from Cocoa Trees in Ibule-Soro, Akure Nigeria”. Acta Scientific Microbiology 1.3 (2018): 08-12. 


\section{Antagonistic result for bacteria isolates}

Test results shows that none of the bacterial isolate had antagonistic effect on selected pathogenic test organisms. Table 5 shows the antagonistic pattern of identified bacterial against selected pathogen.

\begin{tabular}{|l|c|c|c|c|}
\hline \multirow{2}{*}{ I.C } & \multicolumn{3}{c|}{ Selected pathogens } & \multirow{2}{*}{ N.I } \\
\cline { 2 - 4 } & S.A & S.spp. & E.C & \\
\hline K.S & -ve & -ve & -ve & 2 \\
\hline M. Spp & -ve & -ve & -ve & 3 \\
\hline B.C & -ve & -ve & -ve & 2 \\
\hline C.B & -ve & -ve & -ve & 4 \\
\hline
\end{tabular}

Table 5: Antagonistic pattern of identified bacteria against selected pathogen.

Keys: I.C: isolate codes; Kocuria spp; M.S: Micrococcus spp; B.C: Bacillus spp; C.S: Clostridium botulinum. Selected pathogen; S.A; Staphylococcus aureus; S.spp; Shigella spp; E.C; Escherichia coli; N.I: Number of Isolates; 0-10mm: Negative (no antagonism); 11-16mm: Intermediate (mild antagonism); 16-above: Positive (strong antagonism); +ve: positive; -ve: negative (Cheesebrough; 2006).

\section{Antagonistic result for fungi isolates}

Results indicate that only Penicillium notatum had mild antagonistic effect on Escherichia coli and Shigella dysenteriae. Table 6 shows the antagonistic pattern.

\begin{tabular}{|l|c|c|c|c|}
\hline \multirow{2}{*}{ I.C } & \multicolumn{3}{|c|}{ Selected pathogens } & \multirow{2}{*}{ N.I } \\
\cline { 2 - 4 } & S.A & S.D & E.C & \\
\hline P.N & -ve & I & I & 3 \\
\hline M.A & -ve & -ve & -ve & 2 \\
\hline A.F & -ve & -ve & -ve & 2 \\
\hline C.C & -ve & -ve & -ve & 5 \\
\hline H.C & -ve & -ve & -ve & 3 \\
\hline
\end{tabular}

Table 6: Antagonistic pattern of identified fungi against selected pathogen.

Keys: I.C: isolate codes; P.N; Penicillium notatum; M.A; Microsporium audouinii; A.F; Aspergillus flavus; C.C; Cladosporium cladosporioides; H.C; Histoplasma capsulatum. Selected pathogen; S.A; Staphylococcus aureus; S.spp; Shigella dysenteriae; E.C; Escherichia coli. N.I: number of isolates; $0-10 \mathrm{~mm}$ : Negative (no antagonism); 11-16mm: Intermediate (mild antagonism); 16-above: Positive (strong antagonism); +ve: positive; -ve: negative (Cheesebrough; 2006).

Plasmid profiles of bacterial isolates from termitarium and tree bark

The results obtained revealed the presence of plasmid bands of different molecular weights. The molecular weights of the plasmids were determined using DNA- Hind III molecular weight marker (Plate 1). It was observed that Kocuria spp and Micrococcus spp contains plasmid with an estimated molecular weight of $1000 \mathrm{bp}$ and $980 \mathrm{bp}$ respectively.

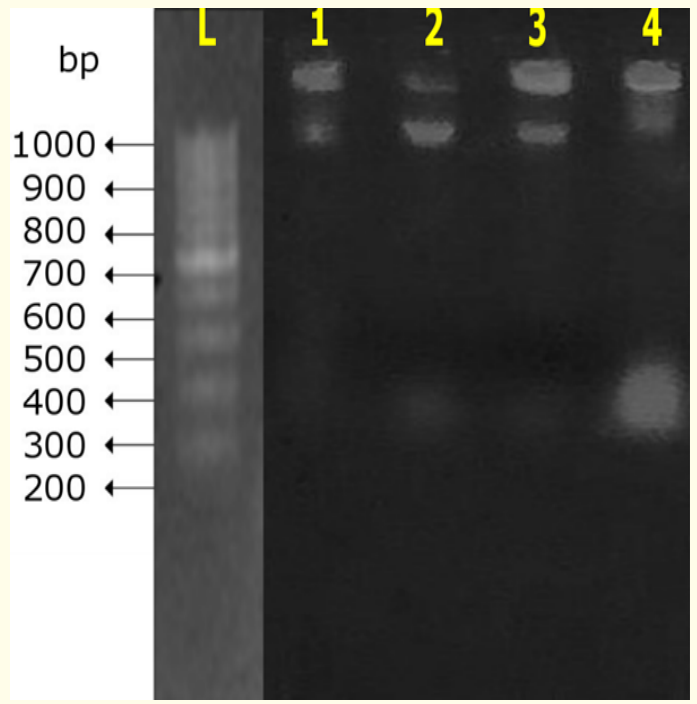

Plate 1: Electrophorogram of Multiple Drug Resistant Bacteria Plasmid DNA.

Keys: L: Gene ladder; 2: Micrococcus spp; 3: Kocuria spp. B: Base Pairs; $1 \mathrm{bp}=3.4$ Angstrom $(\AA)$ while $1000 \mathrm{bp}=1$ kilo base pairs.

Sensitivity result of bacteria isolates from termitarium and tree bark after plasmid curing.

Result shows that Kocuria spp and Micrococcus spp were both sensitive to the generally antibiotics. This makes the initial resistance of this isolates to be plasmid mediated. Thus, resistivity is extra chromosomal in nature.

\begin{tabular}{|l|c|c|c|c|c|c|c|c|c|}
\hline \multirow{8}{*}{ I.C } & \multicolumn{7}{|c|}{$\begin{array}{c}\text { Antibiotic sensitivity patterns after plasmid } \\
\text { curing }\end{array}$} & \multirow{2}{*}{ N.I } \\
\cline { 2 - 9 } & ERY & CXC & OFL & AUG & CAZ & CRS & GEN & CTR & \\
\hline $\begin{array}{l}\text { K. } \\
\text { Spp }\end{array}$ & S & S & S & S & S & S & S & S & 2 \\
\hline $\begin{array}{l}\text { M. } \\
\text { Spp }\end{array}$ & I & I & S & I & I & I & I & I & 3 \\
\hline
\end{tabular}

Table 7: Antibiotic sensitivity pattern of bacteria isolates after plasmid curing.

Keys: I.C: isolate codes; M. Spp; Micrococcus spp; K.spp; Kocuria spp. ERY; Erythromycin; CXC; Cloxacillin; OFL; Ofloxacin; AUG; Augmentin; CAZ: Ceftazidime; CRX; Cefuroxime; GEN; Gentamycin; CTR; Ceftriaxone. N.I: number of isolates; 0-10mm: Resistant; 11-16: Intermediate; 16 -above: Susceptible (Cheesebrough; 2010). S: Susceptible; I: Intermediate; R: Resistant.

\section{Discussion}

The isolated microorganisms which include Kocuria spp, Micrococcus spp, Bacillus spp, Clostridium spp for the bacteria and Penicillium notatum, Microsporium audouinii, Aspergillus flavus, Cladosporium cladosporioides, and Histoplasma capsulatum for fungi indicated the enormous potentials of termitarium sampled from coccoa trees as suitable habitats for microorganisms. Several past studies have pointed to the rich mineral and nutrient contents of the tree gum which is composed of polysaccharides such 
as glucose, mannose, galactose and cellulose; this affords termite nests, bark sheaths and termites inhabiting the tree environments enough growth factors for wide arrays of microorganisms [14,15]. However, some fungi isolates obtained in this study have also been implicated in causing fungal disease in cocoa plant hence, this justifies the presence of this fungi in the samples analysed; this also bears similarities to the findings of Adeigbe., et al [15].

The antagonistic test carried out against selected pathogen revealed Penicillium notatum to show mild antagonistic effect against Shigella dysenteriae and Escherichia coli. Species of Penicillium are ubiquitous as soil and air fungi and their presence in the termitarium indicates a positive mutualism of these fungi isolates and the termite or the termitarium microenvironment themselves. Also, Penicillium notatum has been shown to have the potentials of producing antimicrobials substance against pathogenic microorganism [14].

The bacteria isolates showed varying degrees of resistance to the antibiotics used against them. This could be as a result of the microorganisms being exposed to several chemicals used by the farmers on their crops. The termites on cocoa trees may have also been exposed to some insecticides and their active ingredients which are similar analogues to many of the antibiotics used to evaluate their sensitivity patterns; resulting in possession of resistant (R-factor) plasmids as survival mechanisms against these antimicrobials [15]. Bacteria isolates such as Micrococcus spp, Kocuria spp were screened out to be multiple drug resistant isolates displaying stellar antibiotic resistance against antibiotics used. Plasmid profiling of these organism revealed that the resistance shown is plasmid based as they possess heavy chained resistant factor chromosomes that encode for antibiotic resistance. This also bears similarities with the work of Nicoletti., et al. [14] who shows that antibiotic sensitivity and resistance are often under the control of the bacterial chromosome and that an organism may exhibit resistance to one or several antibiotics as a dominant character determined by genes located on a plasmid (drug resistance $\mathrm{R}$ factors). After curing of the multi-drug resistant organisms of their plasmids, subsequent exposure to broad spectrum antibiotic treatments shows the organisms to be susceptible augmenting the fact that the resistance showed by the organisms before curing was indeed plasmid based, this also agrees with the findings described in Nicoletti., et al [14].

\section{Conclusion}

This study has shown that the termitarium is a microbial habitat that is rich in many nutrients that enables optimum growth of many microbes, revealed the mild antagonistic potentials of Penicillium notatum an isolate obtained from the test samples against known selected pathogens and shown that the possession of resistant factor plasmids is responsible for the antibiotic resistance patterns of multi drug resistances isolate obtained against antibiotic used.

\section{Bibliography}

1. Holt J and Leepage M. "Termites and soil properties: Evolution, sociology, symbiosis, ecology". Kluwer Academic Publication, Amsterdam, the Netherland (2000): 234-244.

2. Longair R. "Tusked males, male dimorphism and nesting behaviour in a sub-social Afro tropical wasp, Synagris cornuta and weapons and dimorphism in the genus (Hymenophera, vespidea, enumenie)". Journal of the Kansas Entromological Society 77.4 (2004): 528-557.

3. Cranshaw W., et al. "Bugs Rule: An Introduction to the World of Insects". Princeton University Press, New Jersey (2013): 188-190.
4. Culliney T and Grace J., "Prospects for the biological control of subterranean termites (Isoptera: Rhinotermitidae), with special reference to Coptotermes formosanus". Bulletin of Entomological Research 90 (2000): 9-21.

5. Divina F and Divina M. "Foods of the Americas". Washington, D.C.: National Museum of the American Indian in association with Ten Speed Press (2004).

6. Dahlquist R M., et al. "Incorporating Livelihoods in Biodiversity Conservation: A Case Study of Cocoa Agroforestry Systems in Talamanca, Costa Rica". Biodiversity and Conservation, Springer Science 16.8 (2007): 2311-2333.

7. Fall S., et al. "Differences between bacterial communities in the gut of a soil-feeding termite (Cubitermes nio- koloensis) and its mounds". Applied and Environmental Microbiology 73.16 (2007): 5199-5208.

8. Fawole M O and Oso B A. "Laboratory manual on microbiology”. Spectrum books limited, Ibadan, Nigeria (2007): 127.

9. Sarah K., et al. "Descriptions of Medical Fungi”. Department of Molecular and Cellular Biology, School of Biological Sciences, University of Adelaide, Australia. $3^{\text {rd }}$ edition (2016).

10. Cheesebrough M. "District laboratory practice in tropical countries". Part 2. Low price edition. Cambridge University Press, London (2006).

11. Fokkema N J and Heuvel J V. "Microbiology of the Phyllosphere". Cambridge [Cambridge shire] New York: Cambridge University Press (1996): 392.

12. Clinical and Laboratory Standards Institute (CLSI). "Performance standards for antimicrobial disk and dilution susceptibility tests for bacteria isolated from animals Approved standard Third edition, CLSI document M31-A3, Clinical and Laboratory Standards Institute, 940 West Valley Road, Wayne Pennsylvania, USA, 28 (2008): 1-99.

13. Brown T. "Vectors for Gene Cloning: Plasmids and Bacteriophages. Gene Cloning and DNA Analysis: An Introduction". Academic Press U.S.A (2010): 64-76.

14. Nicoletti R., et al. "Bioprospecting for antagonistic Penicillium strains as a resource of new antitumor compounds". World Journal of Microbiology 24.2 (2009): 185-195.

15. Adeigbe 0., et al. "Review on cashew research and production in Nigeria in the last four decades". Scientific Research and Essays 10.5 (2015): 196-209.

\section{Volume 1 Issue 3 March 2018 \\ (C) All rights are reserved by J0 Aribisala., et al.}

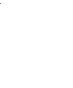

